\title{
PENERAPAN MULTIMEDIA PEMBELAJARAN INTERAKTIF (MPI) DALAM UPAYA MENINGKATKAN HASIL BELAJAR DAN MINAT BELAJAR BIOLOGI
}

\author{
Khudri Fahman Pardosi ${ }^{1}$ dan Abdul Muin Sibuea ${ }^{2}$ \\ SMA Negeri 1 Barus $^{1}$ dan Universitas Negeri Medan ${ }^{2}$ \\ fahmanbarus@gmail.com ${ }^{1}$ dan muin_sibuea@yahoo.com ${ }^{2}$
}

\begin{abstract}
Abstrak: Tujuan penelitian tindakan ini adalah: (1) meningkatkan hasil belajar Biologi dengan penggunaan Multimedia Pembelajaran Interaktif, (2) memperoleh data empiris seberapa besar peningkatan hasil belajar biologi siswa dengan penggunaan Multimedia Pembelajaran Interaktif, (3) meningkatkan minat belajar siswa setelah penggunaan Multimedia Pembelajaran Interaktif dan (4) memperoleh data empiris seberapa besar peningkatan minta belajar biologi siswa dengan penggunaan Multimedia Pembelajaran Interaktif. Jenis penelitian ini adalah Penelitian Tindakan Kelas. Subyek penelitian adalah siswa SMA Negeri 1 Barus kelas XI-1 IPA. Hasil penelitian pra siklus nilai rata-rata $=38,63$ dengan jumlah siswa yang mencapai KKM 4 orang (9\%), nilai ratarata minat belajar awal siswa =2,50 (cukup), nilai rata-rata tes kemampuan akhir hasil belajar siswa di akhir siklus 1 nilai rata-rata $=63,52$ dengan jumlah siswa mencapai KKM sebanyak 27 orang $(61,36 \%)$ dan nilai rata-rata minat belajar akhir siklus $1=2,87$ (baik). Nilai rata-rata tes kemampuan akhir hasil belajar siswa di akhir siklus 2 nilai rata-rata $=76,70$ dengan jumlah siswa mencapai KKM sebanyak 38 orang (86,36\%). Peningkatan hasil belajar siswa dari pra siklus 1 hingga akhir siklus 2 sebesar 77,36\%. Nilai rata-rata minat belajar akhir siklus $2=3,16$ (baik). Peningkatan minat belajar siswa dari pra siklus 1 hingga akhir siklus 2 mencapai 64,59\%.
\end{abstract}

Kata Kunci: Multimedia Pembelajaran Interaktif, Hasil Belajar biologi, Minat Siswa

Abstract: The purpose of this action research are: (1) improve learning outcomes biology with the use of Multimedia Interactive Learning, (2) obtain empirical data on how large an increase in learning outcomes biology student with the use of Multimedia Interactive Learning, (3) increase the interest of student learning after the use of Multimedia Interactive Learning and (4) obtain empirical data on how large an increase'm studying biology student with the use of Multimedia Interactive Learning. This type of research is a classroom action research. Subjects were students of SMAN 1 Barus XI-1 IPA. Results of the study pre-cycle average value $=38.63$ with the number of students who reach KKM 4 people (9\%), the average value of early learning interest of students $=2.50$ (enough), the average value of the end result of learning ability test students at the end of cycle 1 = average value of 63.52 by the number of students reaching the KKM as many as 27 people $(61.36 \%)$ and the average value of the interest in learning the end of cycle $1=2.87$ (good). The average value of the final proficiency test results for students at the end of the second cycle of the average value $=76.70$ with the number of students reaching the KKM as many as 38 people (86.36\%). Improving student learning outcomes of pre-cycle 1 until the end of cycle 2 at $77.36 \%$. The average value of the interest in learning the end of cycle $2=3.16(\mathrm{good})$. Increased student interest in learning from the pre-cycle 1 until the end of cycle 2 reaches $64.59 \%$.

Keywords: Multimedia Interactive Learning, Learning Outcomes biology, Student Interests

\section{PENDAHULUAN}

Peningkatan mutu lulusan lembaga pendidikan harus tetap dilakukan sebagai upaya meningkatkan mutu sumber daya manusia (SDM) baik di tingkat lokal, nasional, dan global. Sumber daya manusia yang handal diharapkan dapat berperan secara aktif dalam memberikan andil bagi peningkatan pembangunan lokal dan nasional, penyediaan tenaga kerja yang handal dan professional, serta dapat menyediakan atau membuka lapangan pekerjaan. Kalau diperhatikan, ada empat aspek globalisasi, yaitu perdagangan, pergerakan modal, pergerakan orang dan penyebaran ilmu pengetahuan dan teknologi.

Menurut Indrajit (2006: 94), pergerakan bebas ilmu pengetahuan dan teknologi yang merupakan salah satu aspek 
penting dalam globalisasi tentu akan menyentuh pula bidang pendidikan. Pendidikan harus mampu berperan dan menyiapkan peserta didik dalam konstelasi masyarakat global dengan tetap melestarikan karakter nasional (Fasli Jalal, 2001: 18). Untuk mengantisipasi tuntutan tersebut, maka Departemen Pendidikan Nasional meluncurkan beberapa kebijakan utama, yaitu pendidikan guru, penerapan teknologi dalam pendidikan, penyempurnaan kurikulum, pengelolaan pendidikan dasar, menengah dan tinggi, pengembangan penelitian dan evaluasi keberhasilan pendidikan nasional Supriyoko: 2003: xxvii).

Dalam penyempurnaan kurikulum dibuktikan dengan lahirnya KTSP (Kurikulum Tingkat Satuan Pendidikan) 2006, yaitu sebuah kurikulum berbasis kompetensi yang mencoba menjawab tantangan pendidikan. Sebagai sebuah kurikulum yang baru diharapkan KTSP 2006 ini dapat diterapkan di setiap satuan pendidikan dalam rangka pembaharuan kegiatan pembelajaran meliputi penetapan pengalaman kegiatan pembelajaran, pengembangan sumber dan alat/bahan belajar secara optimal serta penilaian hasil belajar yang objektif.

Penerapan KTSP 2006 dalam pembelajaran Biologi menuntut kegiatan aktif siswa dalam membangun makna atau pemahaman terhadap suatu konsep, sehingga dalam proses pembelajaran Biologi siswa dijadikan sebagai sentral kegiatan atau pelaku utama, sedangkan guru hanya menciptakan suasana yang dapat mendorong timbulnya motivasi dan kreativitas belajar siswa. Tetapi pada kenyataannya, masih banyak guru yang menganut paradigm lama yang terkenal dengan istilah transfer pengetahuan (transfer of knowledge) dalam pembelajaran biologi masa kini. Hal ini tidak sesuai dengan tujuan pembelajaran Biologi di mana seharusnya guru, menurut Fried dan Hademenos (2005:1) menekankan pada pendekatan objektif saintis dalam memahami fenomena-fenomena yang dipelajari di alam menuntut pada kegiatan pembelajaran yang kreatif.

Salah satu masalah utama dalam pembelajaran Biologi adalah bagaimana menghubungkan fakta yang pernah dilihat dan dialami siswa dalam kehidupan sehari-hari dengan konsep materi ajar Biologi. Umumnya pemahaman siswa terpaku pada jabaran konsep Biologi yang ada dalam buku, tanpa memahami apa dan bagaimana maknanya. Kenyataan di lapangan masih banyak ditemukan keingintahuan anak yang tinggi itu tidak didukung oleh suatu kondisi pembelajaran yang dapat memberikan kesempatan kepada mereka untuk dapat lebih berkembang. Hampir 90\% guru mengajar hanya menggunakan metode dan media konvensional. Guru merupakan satusatunya sumber utama pengetahuan. Pembelajaran cenderung berorientasi pada buku (text book oriented) dan tidak terkait dengan kehidupan sehari-hari siswa. Siswa kesulitan untuk memahami konsep yang telah diajarkan. Konsep-konsep tersebut diajarkan menggunakan cara-cara yang abstrak dan metode konvensional dengan cara menghafal materi ajar secara kaku, padahal mereka sangat memerlukan pemahaman konsep-konsep yang berhubungan dengan lingkungan kehidupan sehari-hari. Akibatnya, motivasi, minat dan semangat belajar siswa sulit ditumbuhkan dan pola belajar mereka cenderung menghafal dan mekanistik.

Mencermati situasi dan kondisi pembelajaran di sekolah, seharusnya guru dan pihak sekolah khususnya mampu memahami kebutuhan mendasar yang diperlukan dalam proses belajar. Menurut Mulyasa, (2007: 54) sebuah lembaga pendidikan harus mampu mencermati kebutuhan peserta didik yang bervariasi, keinginan tenaga kependidikan yang berbeda, kondisi leingkungan yang beragam, harapan masyarakat dan kebijakan pemerintah dalam bidang pendidikan. Sebagai implikasinya, terhadap pembelajaran salah satunya adalah perlu diupayakan lingkungan belajar yang kondusif dengan metode dan media yang bervariasi, sehingga setiap peserta didik belajar dengan menyenangkan.

Lebih jauh lagi dengan penerapan media pembelajaran yang tepat akan memberi beberapa peluang yang terbaik bagi siswa untuk menumbuhkan nilai-nilai positif, yaitu (1) memberikan peluang bagi siswa untuk melibatkan diri secara aktif dalam proses pembelajaran, (2) memberikan kesempatan bagi siswa untuk merekonstruksi pengetahuan secara lebih baik, (3) mendorong siswa untuk mengembangkan sendiri pengalaman belajarnya sesuai strategi yang diminatinya, (4) mendorong siswa agar lebih bertanggung jawab dan berani mengambil resiko, (5) memberikan kesempatan dan kebebasan menyampaikan ide dan pendapat atau mendengaran ide temannya secara leluasa, Sullivan (dalam Ningsih, 2010: 5). 
Salah satu media yang sesuai untuk mengantisipasi hal tersebut perlu didukung media pembelajaran yang sesuai, yaitu Multimedia Pembelajaran Interaktif (MPI). Penggunaan MPI sebagai salah satu media pembelajaran diharapkan dapat membantu efektivitas proses pembelajaran serta penyampaian pesan (isi) pelajaran, selain itu juga akan memberikan penguasaan konsep yang sebenarnya secara realistis dan juga dapat membangkitkan minat dan kreativitas belajar siswa. Hal ini disebabkan karena kemampuan media MPI yang menggabungkan dua unsur atau lebih media yang terdiri atas teks, grafis, gambar, foto, audio, video, dan animasi secara terintegrasi. Multimedia ini berjalan sekuensial (berurutan). MPI adalah suatu multimedia yang dilengkapi dengan pengontrol yang dioperasikan oleh pengguna, sehingga pengguna dapat memilih apa yang dikehendaki untuk proses selanjutnya. Contoh multimedia interaktif adalah multimedia pembelajaran interaktif dalam bentuk CD pembelajaran, aplikasi game, tutorial, drill and practie dan lain-lain.

Beberapa pakar MPI (Setiawan, 2007: 56), mengemukakan bahwa model pembelajaran MPI diartikan sebagai suatu model pembelajaran yang dapat digunakan untuk menyalurkan pesan (message), merangsang pikiran, perasaan, perhatian dan kemauan siswa sehingga dapat mendorong proses belajar. Bentuk-bentuk media digunakan untuk meningkatkan pengalaman belajar agar menjadi lebih konkret. Pengajaran menggunakan media tidak hanya sekedar menggunakan kata-kata (simbol verbal). Dengan demikian, dapat kita harapkan hasil pengalaman belajar lebih berarti bagi siswa.

Model pembelajaran MPI adalah proses pembelajaran di mana penyampaian materi, diskusi, dan kegiatan pembelajaran lain dilakukan melalui media komputer (Darmadi, 2007: 39). Pengertian interaktif terkait dengan komunikasi 2 arah atau lebih dari komponen-komponen komunikasi. Komponen komunikasi dalam multimedia interaktif (berbasis komputer) adalah hubungan antara manusia (sebagai user/pengguna produk) dan komputer (software/aplikasi/produk dalam format file tertentu, biasanya dalam bentuk CD). Dengan demikian produk/CD/aplikasi yang diharapkan memiliki hubungan 2 arah/timbal balik antara software/aplikasi dengan user-nya (Harto, 2008: 20).
Interaktifitas dalam multimedia oleh Zeemry (2008: 30) diberikan batasan sebagai berikut: (1) pengguna (user) dilibatkan untuk berinteraksi dengan program aplikasi; (2) aplikasi informasi interaktif bertujuan agar pengguna bisa mendapatkan hanya informasi yang diinginkan saja tanpa harus "melahap" materi yang ada dan belum dibutuhkan oleh siswa.

Penggunaan multimedia pembelajaran interaktif dalam kegiatan pembelajaran Biologi merupakan salah satu upaya yang dilakukan untuk meningkatkan prestasi belajar siswa. Sadiman (2011: 17) mengemukakan bahwa pemakaian media pembelajaran dalam proses belajar mengajar dapat memperjelas penyajian pesan agar tidak terlalu bersifat verbalistis, mengatasi keterbatasan ruang dan waktu, serta dapat membangkitkan keinginan dan minat yang baru, membangkitkan motivasi dan rangsangan kegiatan pembelajaran dan bahkan membawa pengaruh-pengaruh psikologis terhadap siswa.

Penggunaan media pembelajaran secara tepat dan bervariasi dapat mengatasi sikap pasif menjadi lebih pada anak didik dalam belajar dan dapat meningkatkan kemampuan mengingat informasi materi ajar dan perkembangan inteligensi ganda. Harapan dari tujuan belajar ini sesuai pendapat Nelson (2001: 10), "Concepts and information learned must be actively used si that the brain transfers learning from short-term to long term memory". Penerapan multimedia dapat meningkatkan kualitas mengingat anak dari ingatan jangka pendek menjadi ingatan jangka panjang.

\begin{tabular}{ccc} 
Multimedia & \multicolumn{2}{c}{ pembelajaran } \\
merupakan lingkungan belajar berbasis
\end{tabular} komputer yang memanfaatkan fleksibilitas komputer untuk memecahkan masalah-masalah belajar. Menurut Lee \& Owens (2004: 181), sebagaimana kebanyakan sistem mengajar, komputer dapat digunakan sebagai alat mengajar untuk memberi penguatan belajar, merangsang untuk belajar, dan memotivasi untuk belajar. Banyak manfaat yang diperoleh dari fleksibilitas komputer karena dapat memasukkan video, audio, elemen-elemen grafis, bentuk-bentuk tampilan, dan proses pembelajaran.

Menurut Smaldino (2012: 15), "Jika seorang guru ingin meningkatkan hasil belajar, minat dan aktivitas belajar siswa, maka salah satu perubahan yang dilakukan adalah merubah 
lingkungan (kondisi) belajar siswa". Salah satu bentuk perubahan lingkungan adalah lingkungan fisik berupa penggunaan teknologi dan media pembelajaran yang tepat. Selain itu media pembelajaran juga dapat memudahkan penafsiran data dan memadatkan informasi. Hal ini memungkinkan tercapainya tujuan pembelajaran Biologi, aktivitas belajar, hasil belajar dan minat belajar.

Aspek minat terdiri atas aspek kognitif dan aspek afektif. Aspek kognitif berupa konsep positif terhadap suatu objek dan berpusat pada manfaat dari objek tersebut. Aspek afektif tampak rasa suka atau tidak senang terhadap objek tersebut (Taufani, 2008:39). Minat terhadap mata pelajaran biologi yang dimiliki seseorang bukan bawaan sejak lahir, tetapi dipelajari melalui proses penilaian kognitif dan penilaian afektif seseorang yang dinyatakan dalam sikap. Dengan kata lain, jika proses penilaian kognitif dan afektif seseorang terhadap objek minat adalah positif maka akan menghasilkan sikap positif dan menimbulkan minat.

Minat merupakan salah satu faktor pokok untuk meraih sukses dalam studi. Salah satu sebab utama dari kegagalan studi para pelajar menunjukkan bahwa penyebabnya adalah kekurangan minat (Gie, 1998: 68). Menurut Gie (1998: 70), arti penting minat belajar dalam kaitannya dengan pelaksanaan studi adalah: 1) Minat melahirkan perhatian yang serta merta, 2) Minat memudahnya terciptanya konsentrasi, 3) Minat mencegah gangguan dari luar, 4) Minat memperkuat melekatnya bahan pelajaran dalam ingatan, dan 5) Minat memperkecil kebosanan belajar belajar dalam diri sendiri.

Berdasarkan penjelasan yang telah diuraikan di atas, maka penulis tertarik untuk melakukan sebuah penelitian tindakan kelas (PTK) tentang pemanfaatan MPI dalam pembelajaran Biologi dalam rangka memperbaiki kualitas pembelajaran di kelas dan pada akhirnya dapat meningkatkan hasil belajar Biologi dan minat belajar siswa.

Tujuan penelitian tindakan ini adalah: (1) Untuk memperbaiki kondisi pembelajaran dalam upaya meningkatkan hasil belajar Biologi siswa kelas XI-1 IPA SMA Negeri 1 Barus melalui penerapan Multimedia
Pembelajaran Interaktif, (2) Untuk memperoleh data empiris seberapa besar peningkatan hasil belajar biologi siswa dengan penerapan Multimedia Pembelajaran Interaktif, (3) Untuk memperbaiki kondisi pembelajaran dalam upaya meningkatkan minat belajar biologi siswa kelas XI-1 IPA SMA Negeri 1 Barus melalui penerapan Multimedia Pembelajaran Interaktif, (4) Untuk memperoleh data empiris besar peningkatan minat belajar biologi siswa dengan penerapan Multimedia Pembelajaran Interaktif.

\section{METODE}

Penelitian ini dilakukan di Kelas XI-1 IPA SMA Negeri 1 Barus yang berada di Jalan KS. Tubun Nomor 2 Barus, Kabupaten Tapanuli Tengah-Sumatera Utara. Subjek penelitian adalah seluruh siswa kelas XI-1 IPA yang berjumlah 44 orang siswa. Objek penelitian adalah penggunaan media MPI dalam pembelajaran Biologi pada pembelajaran materi pokok Sistem Peredaran Darah Manusia dan Hewan. Jenis penelitian ini adalah penelitian tindakan kelas (Classroom Action Research).

Variabel dalam penelitian ini terdiri dari tiga macam, yaitu: (1) Multimedia Pembelajaran Interaktif (MPI), (2) Hasil Belajar Biologi dan (3) Minat Belajar Biologi. Untuk memperjelas keterangan ketiga variabel tersebut sebagai berikut: (1) Multimedia Pembelajaran Interaktif (MPI) adalah suatu jenis pemanfaatan media belajar berbasis multimedia (komputer) dengan segala jenis aplikasinya yang digunakan dalam kegiatan pembelajaran Biologi. Dalam hal ini jenis yang digunakan adalah format perpaduan antara drill and practise dan tutorial dalam pembelajaran biologi di laboratorium komputer; (2) Hasil belajar biologi adalah penguasaan konsep (aspek kognitif) yang dipelajari oleh siswa dalam materi pembelajaran Struktur dan Fungsi Organ Manusia dan Hewan; (3) Minat belajar Biologi siswa adalah kecendurungan hati seseorang siswa untuk belajar Biologi secara terarah kepada suatu obyek tertentu yang dinyatakan dalam berbagai tindakan, karena adanya suatu perhatian dan perasaan tertarik pada obyek dan akan timbul apabila mendapatkan rangsangan dari luar.

Tabel 1. Aspek yang diamati dalam Alat Pengumpulan Data

\begin{tabular}{|l|l|l|c|c|}
\hline \multicolumn{1}{|c|}{ Jenis } & \multicolumn{1}{c|}{ Aspek yang diamati } & Jenis Data & Instrument & Waktu \\
\hline Tes & Hasil belajar siswa & Tes hasil & Tes dengan & Di awal dan \\
\hline
\end{tabular}




\begin{tabular}{|c|c|c|c|c|}
\hline & & belajar & objektif tes & $\begin{array}{l}\text { Akhir kegiatan } \\
\text { pembelajaran }\end{array}$ \\
\hline Angket & Minat belajar siswa & $\begin{array}{l}\text { Angket Minat } \\
\text { Belajar }\end{array}$ & $\begin{array}{l}\text { Non tes } \\
\text { dalam bentuk } \\
\text { angket }\end{array}$ & $\begin{array}{l}\text { Di awal dan } \\
\text { Akhir kegiatan } \\
\text { pembelajaran }\end{array}$ \\
\hline $\begin{array}{l}\text { Observa } \\
\text { si }\end{array}$ & $\begin{array}{l}\text { - Proses tindakan } \\
\text { - Aktifitas siswa dalam kegiatan } \\
\text { pembelajaran } \\
\text { - Persoalan lain yang timbul } \\
\text { selama kegiatan PTK }\end{array}$ & $\begin{array}{l}\text { - Observasi } \\
\text { aktifitas guru } \\
\text { dalam } \\
\text { pembelajaran } \\
\text { - Observasi } \\
\text { aktifitas } \\
\text { siswa dalam } \\
\text { pembelajaran }\end{array}$ & $\begin{array}{l}\text { Lembar } \\
\text { Observasi }\end{array}$ & $\begin{array}{l}\text { Kegiatan } \\
\text { pembelajaran } \\
\text { di kelas }\end{array}$ \\
\hline $\begin{array}{l}\text { Wawanc } \\
\text { ara }\end{array}$ & $\begin{array}{l}\text { Mengetahui situasi dalam kelas } \\
\text { dari sudut pandang orang lain } \\
\text { untuk memperkaya data yang } \\
\text { dibutuhkan dalam bentuk } \\
\text { rekaman audio dan catatan. }\end{array}$ & $\begin{array}{l}\text { Hasil } \\
\text { wawancara }\end{array}$ & $\begin{array}{l}\text { Lembar } \\
\text { wawancara }\end{array}$ & $\begin{array}{l}\text { Akhir kegiatan } \\
\text { pembelajaran }\end{array}$ \\
\hline Catatan & $\begin{array}{l}\text { Catatan pribadi tentang } \\
\text { pengamatan, perasaan, tanggapan, } \\
\text { penafsiran, refleksi, firasat, } \\
\text { hipotesis dan penjelasan, juga } \\
\text { kejadian-kejadian khusus yang } \\
\text { bisa merekontruksikan kejadian } \\
\text { pada saat itu. }\end{array}$ & $\begin{array}{l}\text { - Jurnal } \\
\text { harian } \\
\text { - Catatan } \\
\text { - Lapangan }\end{array}$ & $\begin{array}{l}\text { Jurnal harian } \\
\text { Catatan } \\
\text { Lapangan }\end{array}$ & $\begin{array}{l}\text { Kegiatan } \\
\text { pembelajaran } \\
\text { di } \\
\text { laboratorium } \\
\text { dan kelas }\end{array}$ \\
\hline $\begin{array}{l}\text { Dokume } \\
\mathrm{n}\end{array}$ & $\begin{array}{l}\text { - Kurikulum dan pedoman } \\
\text { pelaksanaannya } \\
\text { - Selabus dan rencana pengajaran } \\
\text { - Hasil ujian } \\
\text { - Bagian-bagian dari buku teks } \\
\text { - Laporan tugas siswa }\end{array}$ & $\begin{array}{l}\text { - Silabus } \\
\text { - RPP } \\
\text { - LKS } \\
\text { - Hasil ujian }\end{array}$ & $\begin{array}{l}\text { Format } \\
\text { rancangan } \\
\text { evaluasi } \\
\text { pembelajaran }\end{array}$ & $\begin{array}{l}\text { Awal kegiatan } \\
\text { pembelajaran }\end{array}$ \\
\hline $\begin{array}{l}\text { Photo } \\
\text { dan } \\
\text { rekaman }\end{array}$ & $\begin{array}{l}\text { MengGambarkan aktifitas yang } \\
\text { sedang terjadi pada saat } \\
\text { pembelajaran termasuk suasana } \\
\text { kelas, detail tentang peristiwa, } \\
\text { atau ilustrasi }\end{array}$ & $\begin{array}{l}\text { - Photo } \\
\text { kegiatan } \\
\text { pembelajaran } \\
\text { - Rekaman } \\
\text { hasil } \\
\text { wawancara }\end{array}$ & & $\begin{array}{l}\text { Kegiatan } \\
\text { pembelajaran } \\
\text { di } \\
\text { laboratorium } \\
\text { dan ruang } \\
\text { kelas }\end{array}$ \\
\hline
\end{tabular}

\section{HASIL DAN PEMBAHASAN}

\section{Hasil}

Kemampuan awal siswa (aspek kognitif) dianalisis melalui data hasil tes awal. Tes awal dilakukan untuk mengetahui kemampuan awal siswa. Berdasarkan hasil tes kemampuan awal yang telah dianalisis maka diperoleh nilai rata-rata $=38,63$; nilai tertinggi $=70$; nilai terendah $=$ 10, jumlah siswa yang tuntas 4 orang (9\%), tidak tuntas 40 orang $(91 \%)$ dengan nilai KKM 70.

\section{Hasil Angket Minat Belajar Awal Siswa Pra Siklus 1}

Tabel 2. Deskripsi Hasil Angket Minat Belajar Awal Siswa Pra Siklus 1

\begin{tabular}{|c|l|c|c|}
\hline \multirow{2}{*}{ No } & \multicolumn{2}{|c|}{ Indikator } & \multicolumn{2}{c|}{ Skor Rata-rata dan Kriteria } \\
\cline { 3 - 4 } & & Rata-rata Indikator & Kriteria \\
\hline 1 & Sikap dalam belajar & 2,90 & Baik \\
\hline 2 & Kemauan belajar & 2,68 & Baik \\
\hline 3 & Ketertarikan dalam belajar & 2,38 & Cukup \\
\hline
\end{tabular}




\begin{tabular}{|c|l|c|c|}
\hline 4 & Dorongan belajar & 2,29 & Cukup \\
\hline 5 & Ketekunan dalam belajar & 2,45 & Cukup \\
\hline 6 & Perhatian dalam aktivitas belajar & 2,88 & Baik \\
\hline & Jumlah & 15,00 & 2,50 (Cukup) \\
\hline & Rata-rata & \multicolumn{2}{|c|}{3,11} \\
\hline & Max & \multicolumn{2}{|c|}{1,93} \\
\hline & Min &
\end{tabular}

\section{Data Hasil Angket Minat Belajar Siswa Siklus 1}

Tabel 3. Deskripsi Hasil Angket Minat Belajar Siklus 1

\begin{tabular}{|c|l|c|c|}
\hline \multirow{2}{*}{ No } & \multicolumn{2}{|c|}{ Indikator } & \multicolumn{2}{|c|}{ Siklus 1 } \\
\cline { 3 - 4 } & & Rata-rata Indikator & Kriteria \\
\hline 1 & Sikap dalam belajar & 3,00 & Baik \\
\hline 2 & Kemauan belajar & 3,04 & Baik \\
\hline 3 & Ketertarikan dalam belajar & 2,50 & Cukup \\
\hline 4 & Dorongan belajar & 2,65 & Baik \\
\hline 5 & Ketekunan dalam belajar & 2,92 & Baik \\
\hline 6 & Perhatian dalam aktivitas belajar & 3,08 & Baik \\
\hline & Jumlah & 17,19 & \multicolumn{2}{|c|}{2,87 (Baik) } \\
\hline & Rata-rata & \multicolumn{2}{|c|}{2,50} \\
\hline & Max & \multicolumn{2}{|c|}{$9 \%$} \\
\hline & Min & \multicolumn{2}{|c|}{} \\
\hline & Persentase peningkatan dari Pra Siklus 1 & \multicolumn{2}{|c|}{} \\
\hline
\end{tabular}

\section{Data Hasil Observasi Aktivitas Guru Siklus 1}

Tabel 4. Rekapitulasi Hasil Observasi Aktivitas Guru Pada Siklus 1

\begin{tabular}{|c|c|c|c|c|c|c|c|c|c|}
\hline \multirow{3}{*}{ No } & \multirow{3}{*}{ Indikator } & \multicolumn{8}{|c|}{ Siklus 1/ Pertemuan ke- } \\
\hline & & \multicolumn{2}{|c|}{1} & \multicolumn{2}{|c|}{2} & \multicolumn{2}{|c|}{3} & \multicolumn{2}{|c|}{4} \\
\hline & & Skor & $\%$ & Skor & $\%$ & Skor & $\%$ & Skor & $\%$ \\
\hline 1 & $\begin{array}{l}\text { Ketrampilan membuka } \\
\text { pelajaran }\end{array}$ & 3 & 75 & 4 & 100 & 4 & 100 & 4 & 100 \\
\hline 2 & Penyajian materi & 3 & 75 & 3 & 75 & 3 & 75 & 3 & 75 \\
\hline 3 & Strategi Pembelajaran & 3 & 75 & 3 & 75 & 3 & 75 & 3 & 75 \\
\hline 4 & $\begin{array}{l}\text { Pemanfaatan MPI dalam } \\
\text { Pembelajaran }\end{array}$ & 3 & 75 & 3 & 75 & 3 & 75 & 3 & 75 \\
\hline 5 & Pengelolaan Kelas & 3 & 75 & 3 & 75 & 4 & 100 & 4 & 100 \\
\hline 6 & Penilaian pembelajaran & 3 & 75 & 3 & 75 & 3 & 75 & 4 & 100 \\
\hline 7 & $\begin{array}{l}\text { Ketrampilan menutup } \\
\text { pelajaran }\end{array}$ & 3 & 75 & 3 & 75 & 3 & 75 & 3 & 75 \\
\hline 8 & $\begin{array}{l}\text { Sikap Guru selama } \\
\text { pembelajaran }\end{array}$ & 3 & 75 & 3 & 75 & 3 & 75 & 3 & 75 \\
\hline \multirow[t]{3}{*}{9} & Efesiensi penggunaan waktu & 2 & 50 & 2 & 50 & 2 & 50 & 2 & 50 \\
\hline & Jumlah skor & 26 & & 27 & & 28 & & 29 & \\
\hline & $\begin{array}{r}\text { Jumlah rata-rata } \% / \text { tatap } \\
\text { muka }\end{array}$ & & $\begin{array}{c}72, \\
2 \\
\end{array}$ & & 75 & & $\begin{array}{c}77, \\
8\end{array}$ & & 80,6 \\
\hline
\end{tabular}




\begin{tabular}{|r|r|c|c|c|c|}
\cline { 3 - 5 } & Kategori & Baik & Baik & Baik & Baik \\
\hline Observer & H. Tamba & Widiawati & N. Rambe & Widiawati \\
\hline & Rata-rata Siklus & \multicolumn{4}{|c|}{$76.38 \%$} \\
\hline
\end{tabular}

\section{Data Hasil Observasi Aktivitas Siswa Siklus 1}

Hasil observasi aktivitas siswa pertemuan pertama hingga keempat pada siklus 1 disajikan pada Tabel 5 berikut.

Tabel 5. Rekapitulasi Hasil Observasi Aktivitas Siswa Pada Siklus 1

\begin{tabular}{|c|c|c|c|c|c|c|c|c|c|}
\hline \multirow{3}{*}{ No } & \multirow{3}{*}{ Aspek aktivitas siswa yang diamati } & \multicolumn{8}{|c|}{ SIKLUS 1} \\
\hline & & \multicolumn{2}{|r|}{1} & \multicolumn{2}{|r|}{2} & \multicolumn{2}{|r|}{3} & \multicolumn{2}{|r|}{4} \\
\hline & & $\mathrm{F}$ & $\%$ & $\mathrm{~F}$ & $\%$ & $\mathrm{~F}$ & $\%$ & $\mathrm{~F}$ & $\%$ \\
\hline 1. & $\begin{array}{l}\text { Mendengar/ memperhatikan } \\
\text { penjelasan guru }\end{array}$ & 31 & 70,45 & 33 & 75,00 & 36 & 81,82 & 37 & 84,09 \\
\hline 2. & $\begin{array}{l}\text { Mendengar/ memperhatikan } \\
\text { penjelasan dari media MPI }\end{array}$ & 32 & 72,73 & 36 & 81,82 & 38 & 86,36 & 39 & 88,64 \\
\hline 3. & $\begin{array}{l}\text { Mendengar/ memperhatikan } \\
\text { penjelasan teman }\end{array}$ & 31 & 70,45 & 36 & 81,82 & 36 & 81,82 & 37 & 84,09 \\
\hline 4. & Mengajukan pertanyaan & 30 & 68,18 & 33 & 75,00 & 35 & 79,55 & 39 & 88,64 \\
\hline 5. & $\begin{array}{l}\text { Antusias dalam pembelajaran } \\
\text { menggunakan MPI }\end{array}$ & 33 & 75,00 & 38 & 86,36 & 38 & 86,36 & 38 & 86,36 \\
\hline 6. & Diskusi dengan teman sesama siswa & 35 & 79,55 & 36 & 81,82 & 36 & 81,82 & 36 & 81,82 \\
\hline 7. & Diskusi dengan guru & 33 & 75,00 & 33 & 75,00 & 35 & 79,55 & 39 & 88,64 \\
\hline 8. & $\begin{array}{l}\text { Kemampuan memberikan ide-ide } \\
\text { pemecahan masalah }\end{array}$ & 34 & 77,27 & 34 & 77,27 & 36 & 81,82 & 39 & 88,64 \\
\hline 9. & $\begin{array}{l}\text { Memperagakan hasil/ } \\
\text { menyampaikan pendapat/ ide }\end{array}$ & 31 & 70,45 & 33 & 75,00 & 35 & 79,55 & 36 & 81,82 \\
\hline 10. & $\begin{array}{l}\text { Memberikan waktu untuk } \\
\text { mengeluarkan ide-ide }\end{array}$ & 30 & 68,18 & 36 & 81,82 & 36 & 81,82 & 38 & 86,36 \\
\hline 11. & $\begin{array}{l}\text { Kemampuan mencari kombinasi } \\
\text { dari ide-ide penyelesaian masalah }\end{array}$ & 27 & 61,36 & 36 & 81,82 & 38 & 86,36 & 38 & 86,36 \\
\hline 12. & $\begin{array}{l}\text { Kemampuan menghargai pendapat } \\
\text { orang lain }\end{array}$ & 32 & 72,73 & 35 & 79,55 & 38 & 86,36 & 38 & 86,36 \\
\hline 13. & $\begin{array}{l}\text { Kreativitas dalam menyumbangkan } \\
\text { ide-ide }\end{array}$ & 34 & 77,27 & 34 & 77,27 & 36 & 81,82 & 39 & 88,64 \\
\hline 14. & $\begin{array}{l}\text { Kemampuan menemukan jawaban } \\
\text { yang paling tepat dengan } \\
\text { menggunakan MPI }\end{array}$ & 37 & 84,09 & 36 & 81,82 & 36 & 81,82 & 38 & 86,36 \\
\hline 15. & $\begin{array}{l}\text { Kemampuan merumuskan } \\
\text { kesimpulan dengan tepat }\end{array}$ & 33 & 75,00 & 33 & 75,00 & 36 & 81,82 & 36 & 81,82 \\
\hline 16. & $\begin{array}{l}\text { Kemampuan menyelesaikan tugas- } \\
\text { tugas kegiatan siswa dengan baik }\end{array}$ & 32 & 72,73 & 33 & 75,00 & 35 & 79,55 & 36 & 81,82 \\
\hline 17. & $\begin{array}{l}\text { Mengumpulkan tugas dengan tepat } \\
\text { waktu }\end{array}$ & 31 & 70,45 & 35 & 79,55 & 36 & 81,82 & 39 & 88,64 \\
\hline & Persentase Nilai Akhir (NA) & & 72,99 & & 78,88 & & 82,35 & & 85,83 \\
\hline & Kategori & & 3aik & & Baik & & 3aik & & Baik \\
\hline & Observer & & $\mathrm{HT}$ & & WD & & NR & & WD \\
\hline
\end{tabular}

\section{Tahap Refleksi}

Setelah pelaksanaan tindakan pada siklus 1 berakhir, peneliti bersama-sama dengan 3 orang Observer melakukan refleksi terhadap kegiatan yang telah berlangsung. Refleksi yang dilakukan meliputi 4 aspek, yaitu: (a) Refleksi terhadap Proses Pelaksanaan Pembelajaran, (b) 
Refleksi terhadap Aktifitas Siswa, (c) Refleksi terhadap Hasil Pembelajaran Biologi Siswa dan (d) Refleksi terhadap Minat Belajar Siswa.

\section{Tahap Perencanaan}

Sesuai dengan hasil refleksi pada siklus 1, maka kegiatan yang dilakukan pada siklus 2 meliputi perencanaan, pelaksanaan tindakan pembelajaran, peneliti masih bertindak sebagai guru. Kegiatan pembelajaran pada siklus 2 tetap menggunakan media MPI dengan alokasi waktu 4 kali pertemuan. Pada tahap perencanaan siklus 2, peneliti kembali menyiapkan RPP untuk pertemuan 5, 6, 7 dan 8 serta LAS 5, LAS 6, LAS 7 dan LAS 8 yang telah direvisi dengan menambah latihan soal. Selain itu peneliti juga menyiapkan soal tes siklus 2 untuk mengukur kemampuan pengetahuan siswa yang berjumlah 20 soal. Peneliti juga menyiapkan instrumen penelitian lainnya, seperti angket sebanyak 30 item, lembar observasi aktivitas guru dan siswa selama pembelajaran serta pedoman wawancara siswa.

\section{Data Hasil Angket Minat Belajar Siswa Siklus 2}

Tabel 6. Deskripsi Hasil Angket Minat Belajar Siklus 2

\begin{tabular}{|c|c|c|c|c|}
\hline \multirow[b]{2}{*}{ No } & \multirow[b]{2}{*}{ Indikator } & \multicolumn{2}{|c|}{ Siklus 2} & \multirow{2}{*}{$\begin{array}{c}\text { Persentase } \\
\text { Peningkatan dari } \\
\text { Siklus } 1 \text { ke siklus } 2 \\
\end{array}$} \\
\hline & & $\begin{array}{l}\text { Rata-rata } \\
\text { Indikator }\end{array}$ & Kriteria & \\
\hline 1 & Sikap dalam belajar & 3,26 & Baik Sekali & 8,71 \\
\hline 2 & Kemauan belajar & 3,18 & Baik & 4,54 \\
\hline 3 & Ketertarikan dalam belajar & 3,04 & Baik & 21,64 \\
\hline 4 & Dorongan belajar & 3,02 & Baik & 14,07 \\
\hline 5 & Ketekunan dalam belajar & 3,22 & Baik & 10,26 \\
\hline \multirow[t]{7}{*}{6} & $\begin{array}{c}\text { Perhatian dalam aktivitas } \\
\text { belajar }\end{array}$ & 3,25 & Baik & 5,37 \\
\hline & Jumlah & 18,97 & & 64,59 \\
\hline & Rata-rata & 3,16 & Baik & \\
\hline & Max & \multicolumn{3}{|c|}{3,26} \\
\hline & Min & \multicolumn{3}{|c|}{3,02} \\
\hline & $\begin{array}{l}\text { Persentase Peningkatan dari } \\
\text { Siklus } 1\end{array}$ & \multicolumn{3}{|c|}{$7,25 \%$} \\
\hline & $\begin{array}{l}\text { Persentase Peningkatan dari } \\
\text { Pra Siklus }\end{array}$ & \multicolumn{3}{|c|}{$64,59 \%$} \\
\hline
\end{tabular}

\section{Data Hasil Observasi Aktivitas Guru Siklus 2}

Tabel 7. Rekapitulasi Hasil Observasi Aktivitas Guru Pada Siklus 2

\begin{tabular}{|c|c|c|c|c|c|c|c|c|c|}
\hline \multirow{3}{*}{ No } & \multirow{3}{*}{ Indikator } & \multicolumn{8}{|c|}{ Siklus 2} \\
\hline & & \multicolumn{2}{|c|}{5} & \multicolumn{2}{|c|}{6} & \multicolumn{2}{|c|}{7} & \multicolumn{2}{|c|}{8} \\
\hline & & Skor & $\%$ & Skor & $\%$ & Skor & $\%$ & Skor & $\%$ \\
\hline 1 & $\begin{array}{l}\text { Ketrampilan membuka } \\
\text { pelajaran }\end{array}$ & 4 & 100 & 4 & 100 & 4 & 100 & 4 & 100 \\
\hline 2 & Penyajian materi & 3 & 75 & 3 & 75 & 4 & 100 & 4 & 100 \\
\hline 3 & Strategi Pembelajaran & 3 & 75 & 3 & 75 & 4 & 100 & 4 & 100 \\
\hline 4 & $\begin{array}{l}\text { Pemanfaatan MPI dalam } \\
\text { Pembelajaran }\end{array}$ & 4 & 100 & 4 & 100 & 4 & 100 & 4 & 100 \\
\hline 5 & Pengelolaan Kelas & 3 & 75 & 3 & 75 & 3 & 75 & 4 & 100 \\
\hline 6 & Penilaian pembelajaran & 3 & 75 & 3 & 75 & 3 & 75 & 3 & 75 \\
\hline 7 & Ketrampilan menutup & 4 & 100 & 4 & 100 & 3 & 75 & 3 & 75 \\
\hline
\end{tabular}




\begin{tabular}{|c|c|c|c|c|c|c|c|c|c|}
\hline & pelajaran & & & & & & & & \\
\hline 8 & $\begin{array}{l}\text { Sikap Guru selama } \\
\text { pembelajaran }\end{array}$ & 3 & 75 & 3 & 75 & 4 & 100 & 4 & 100 \\
\hline 9 & $\begin{array}{l}\text { Efesiensi penggunaan } \\
\text { waktu }\end{array}$ & 3 & 75 & 3 & 75 & 3 & 75 & 4 & 100 \\
\hline & Jumlah skor & 30 & & 30 & & 32 & & 34 & \\
\hline & $\begin{array}{r}\text { Jumlah rata-rata \% /tatap } \\
\text { muka }\end{array}$ & & 83,3 & & 83,3 & & 88,9 & & 94,4 \\
\hline & Kategori & \multicolumn{2}{|c|}{ Baik } & \multicolumn{2}{|c|}{ Baik } & \multicolumn{2}{|c|}{ Baik Sekali } & \multicolumn{2}{|c|}{ Baik Sekali } \\
\hline & Observer & \multicolumn{2}{|c|}{ Widiawati } & \multicolumn{2}{|c|}{ N. Rambe } & \multicolumn{2}{|c|}{ H. Tamba } & \multicolumn{2}{|c|}{ Widiawati } \\
\hline & Rata-rata Siklus & \multicolumn{8}{|c|}{$87,50 \%$} \\
\hline & $\begin{array}{r}\% \text { Kenaikan Siklus } 1 \text { ke } \\
\text { Siklus } 2\end{array}$ & \multicolumn{8}{|c|}{$18,06 \%$} \\
\hline
\end{tabular}

\section{Data Hasil Observasi Aktivitas Siswa Siklus 2}

Tabel 8. Rekapitulasi Hasil Observasi Aktivitas Siswa Pada Siklus 2

\begin{tabular}{|c|c|c|c|c|c|c|c|c|c|}
\hline \multirow[t]{3}{*}{ No } & \multirow{3}{*}{ Aspek aktivitas siswa yang diamati } & \multicolumn{8}{|c|}{ SIKLUS 2} \\
\hline & & \multicolumn{2}{|c|}{5} & \multicolumn{2}{|c|}{6} & \multicolumn{2}{|c|}{7} & \multicolumn{2}{|c|}{8} \\
\hline & & $\mathbf{F}$ & $\%$ & $\mathbf{F}$ & $\%$ & $\mathbf{F}$ & $\%$ & $\mathbf{F}$ & $\%$ \\
\hline 1. & Mendengar/ memperhatikan penjelasan guru & $\begin{array}{l}3 \\
8\end{array}$ & $\begin{array}{l}86, \\
36\end{array}$ & $\begin{array}{l}4 \\
0\end{array}$ & $\begin{array}{l}90, \\
91\end{array}$ & $\begin{array}{l}4 \\
2\end{array}$ & $\begin{array}{r}95, \\
45\end{array}$ & $\begin{array}{l}4 \\
4\end{array}$ & $\begin{array}{c}100, \\
00\end{array}$ \\
\hline 2. & $\begin{array}{l}\text { Mendengar/ memperhatikan penjelasan dari } \\
\text { media MPI }\end{array}$ & $\begin{array}{l}3 \\
9\end{array}$ & $\begin{array}{l}88, \\
64\end{array}$ & $\begin{array}{l}3 \\
9\end{array}$ & $\begin{array}{l}88, \\
64\end{array}$ & $\begin{array}{l}4 \\
3\end{array}$ & $\begin{array}{l}97, \\
73\end{array}$ & $\begin{array}{l}4 \\
3\end{array}$ & $\begin{array}{c}97,7 \\
3\end{array}$ \\
\hline 3. & Mendengar/ memperhatikan penjelasan teman & $\begin{array}{l}4 \\
0\end{array}$ & $\begin{array}{l}90, \\
91\end{array}$ & $\begin{array}{l}4 \\
0\end{array}$ & $\begin{array}{l}90, \\
91\end{array}$ & $\begin{array}{l}4 \\
1\end{array}$ & $\begin{array}{r}93, \\
18\end{array}$ & $\begin{array}{l}4 \\
2\end{array}$ & $\begin{array}{c}95,4 \\
5\end{array}$ \\
\hline 4. & Mengajukan pertanyaan & $\begin{array}{l}3 \\
9\end{array}$ & $\begin{array}{l}88, \\
64\end{array}$ & $\begin{array}{l}3 \\
9\end{array}$ & $\begin{array}{l}88, \\
64\end{array}$ & $\begin{array}{l}4 \\
2\end{array}$ & $\begin{array}{r}95, \\
45\end{array}$ & $\begin{array}{l}4 \\
3\end{array}$ & $\begin{array}{c}97,7 \\
3\end{array}$ \\
\hline 5. & $\begin{array}{l}\text { Antusias dalam pembelajaran menggunakan } \\
\text { MPI }\end{array}$ & $\begin{array}{l}3 \\
8\end{array}$ & $\begin{array}{l}86, \\
36\end{array}$ & $\begin{array}{l}4 \\
1\end{array}$ & $\begin{array}{r}93, \\
18\end{array}$ & $\begin{array}{l}4 \\
1\end{array}$ & $\begin{array}{r}93, \\
18\end{array}$ & $\begin{array}{l}4 \\
4\end{array}$ & $\begin{array}{c}100, \\
00\end{array}$ \\
\hline 6. & Diskusi dengan teman sesama siswa & $\begin{array}{l}3 \\
6\end{array}$ & $\begin{array}{l}81, \\
82\end{array}$ & $\begin{array}{l}4 \\
0\end{array}$ & $\begin{array}{r}90, \\
91\end{array}$ & $\begin{array}{l}4 \\
2\end{array}$ & $\begin{array}{r}95, \\
45\end{array}$ & $\begin{array}{l}4 \\
2\end{array}$ & $\begin{array}{c}95,4 \\
5\end{array}$ \\
\hline 7. & Diskusi dengan guru & $\begin{array}{l}3 \\
9\end{array}$ & $\begin{array}{l}88, \\
64\end{array}$ & $\begin{array}{l}3 \\
9\end{array}$ & $\begin{array}{l}88, \\
64\end{array}$ & $\begin{array}{l}4 \\
0\end{array}$ & $\begin{array}{l}90, \\
91\end{array}$ & $\begin{array}{l}4 \\
2\end{array}$ & $\begin{array}{c}95,4 \\
5\end{array}$ \\
\hline 8. & $\begin{array}{l}\text { Kemampuan memberikan ide-ide pemecahan } \\
\text { masalah }\end{array}$ & $\begin{array}{l}3 \\
9\end{array}$ & $\begin{array}{l}88, \\
64\end{array}$ & $\begin{array}{l}3 \\
9\end{array}$ & $\begin{array}{c}88, \\
64\end{array}$ & $\begin{array}{l}4 \\
1\end{array}$ & $\begin{array}{r}93, \\
18\end{array}$ & $\begin{array}{l}4 \\
1\end{array}$ & $\begin{array}{c}93,1 \\
8\end{array}$ \\
\hline 9. & $\begin{array}{l}\text { Memperagakan hasil/ menyampaikan } \\
\text { pendapat/ide }\end{array}$ & $\begin{array}{l}3 \\
6\end{array}$ & $\begin{array}{l}81, \\
82\end{array}$ & $\begin{array}{l}4 \\
0\end{array}$ & $\begin{array}{r}90, \\
91\end{array}$ & $\begin{array}{l}4 \\
0\end{array}$ & $\begin{array}{l}90, \\
91\end{array}$ & $\begin{array}{l}4 \\
0\end{array}$ & $\begin{array}{c}90,9 \\
1\end{array}$ \\
\hline 10. & $\begin{array}{l}\text { Memberikan waktu untuk mengeluarkan ide- } \\
\text { ide }\end{array}$ & $\begin{array}{l}3 \\
8\end{array}$ & $\begin{array}{l}86, \\
36\end{array}$ & $\begin{array}{l}4 \\
0\end{array}$ & $\begin{array}{l}90, \\
91\end{array}$ & $\begin{array}{l}4 \\
1\end{array}$ & $\begin{array}{r}93, \\
18\end{array}$ & $\begin{array}{l}4 \\
1\end{array}$ & $\begin{array}{c}93,1 \\
8\end{array}$ \\
\hline 11. & $\begin{array}{l}\text { Kemampuan mencari kombinasi dari ide solusi } \\
\text { masalah }\end{array}$ & $\begin{array}{l}4 \\
0\end{array}$ & $\begin{array}{r}90, \\
91\end{array}$ & $\begin{array}{l}4 \\
0\end{array}$ & $\begin{array}{r}90, \\
91\end{array}$ & $\begin{array}{l}4 \\
1\end{array}$ & $\begin{array}{r}93, \\
18\end{array}$ & $\begin{array}{l}4 \\
2\end{array}$ & $\begin{array}{c}95,4 \\
5\end{array}$ \\
\hline 12. & Kemampuan menghargai pendapat orang lain & $\begin{array}{l}3 \\
8\end{array}$ & $\begin{array}{l}86, \\
36\end{array}$ & $\begin{array}{l}4 \\
1\end{array}$ & $\begin{array}{r}93, \\
18 \\
\end{array}$ & $\begin{array}{l}4 \\
1\end{array}$ & $\begin{array}{r}93, \\
18 \\
\end{array}$ & $\begin{array}{l}4 \\
4\end{array}$ & $\begin{array}{c}100, \\
00\end{array}$ \\
\hline 13. & Kreativitas dalam menyumbangkan ide-ide & $\begin{array}{l}4 \\
0\end{array}$ & $\begin{array}{l}90, \\
91\end{array}$ & $\begin{array}{l}4 \\
0\end{array}$ & $\begin{array}{l}90, \\
91\end{array}$ & $\begin{array}{l}4 \\
2\end{array}$ & $\begin{array}{r}95, \\
45\end{array}$ & $\begin{array}{l}4 \\
2\end{array}$ & $\begin{array}{c}95,4 \\
5\end{array}$ \\
\hline 14. & $\begin{array}{l}\text { Kemampuan menemukan jawaban yang paling } \\
\text { tepat }\end{array}$ & $\begin{array}{l}3 \\
8\end{array}$ & $\begin{array}{l}86, \\
36\end{array}$ & $\begin{array}{l}4 \\
1\end{array}$ & $\begin{array}{l}93, \\
18 \\
\end{array}$ & $\begin{array}{l}4 \\
1\end{array}$ & $\begin{array}{r}93, \\
18 \\
\end{array}$ & $\begin{array}{l}4 \\
1\end{array}$ & $\begin{array}{c}93,1 \\
8\end{array}$ \\
\hline 15. & $\begin{array}{l}\text { Kemampuan merumuskan kesimpulan dengan } \\
\text { tepat }\end{array}$ & $\begin{array}{l}3 \\
7\end{array}$ & $\begin{array}{l}84, \\
09\end{array}$ & $\begin{array}{l}3 \\
9 \\
\end{array}$ & $\begin{array}{l}88, \\
64 \\
\end{array}$ & $\begin{array}{l}4 \\
2 \\
\end{array}$ & $\begin{array}{r}95, \\
45 \\
\end{array}$ & $\begin{array}{l}4 \\
2 \\
\end{array}$ & $\begin{array}{c}95,4 \\
5\end{array}$ \\
\hline 16. & Kemampuan menyelesaikan tugas-tugas & $\begin{array}{l}3 \\
6\end{array}$ & $\begin{array}{l}81, \\
82\end{array}$ & $\begin{array}{l}3 \\
9\end{array}$ & $\begin{array}{c}88, \\
64\end{array}$ & $\begin{array}{l}4 \\
2 \\
\end{array}$ & $\begin{array}{r}95, \\
45\end{array}$ & $\begin{array}{l}4 \\
4 \\
\end{array}$ & $\begin{array}{c}100, \\
00\end{array}$ \\
\hline
\end{tabular}




\begin{tabular}{|r|r|r|c|c|c|c|c|c|c|} 
17. & Mengumpulkan tugas dengan tepat waktu & 4 & 90, & 4 & 90, & 4 & 95, & 4 & 100, \\
& 0 & 91 & 0 & 91 & 2 & 45 & 4 & 00 \\
\hline & Persentase Nilai Akhir (NA) & & $\begin{array}{c}\mathbf{8 7}, \\
\mathbf{0 3}\end{array}$ & & $\mathbf{9 0 ,}$ & $\mathbf{5 1}$ & $\mathbf{9 4 ,}$ & $\mathbf{1 2}$ & $\begin{array}{c}\mathbf{9 6 , 3} \\
\mathbf{9}\end{array}$ \\
\hline & Kategori & $\begin{array}{c}\text { Baik } \\
\text { sekali }\end{array}$ & $\begin{array}{c}\text { Baik } \\
\text { sekali }\end{array}$ & $\begin{array}{c}\text { Baik } \\
\text { sekali }\end{array}$ & $\begin{array}{c}\text { Baik } \\
\text { sekali }\end{array}$ \\
\hline & Observer & WD & NR & HT & WD \\
\hline
\end{tabular}

\section{Data Hasil Catatan Lapangan dan Wawancara Siklus 2}

Tabel 9. Rekapitulasi Hasil Observasi Aktivitas Guru Siklus 1 - Siklus 2

\begin{tabular}{|c|c|c|c|c|c|c|c|c|c|}
\hline \multirow{2}{*}{ No } & \multirow{2}{*}{ Indikator } & \multicolumn{4}{|c|}{ Siklus 1} & \multicolumn{4}{|c|}{ Siklus 2} \\
\hline & & 1 & 2 & 3 & 4 & 5 & 6 & 7 & 8 \\
\hline 1 & Jumlah skor & 26 & 27 & 28 & 29 & 30 & 30 & 32 & 34 \\
\hline 2 & $\begin{array}{l}\text { Jumlah rata- } \\
\text { rata \% /tatap } \\
\text { muka }\end{array}$ & 72,2 & 75 & 77,8 & 80,6 & 83,3 & 83,3 & 88,9 & 94,4 \\
\hline 3 & Kategori & Baik & Baik & Baik & Baik & Baik & Baik & $\begin{array}{c}\text { Baik } \\
\text { Sekali }\end{array}$ & $\begin{array}{c}\text { Baik } \\
\text { Sekkali }\end{array}$ \\
\hline 4 & Observer & $\begin{array}{c}\text { H. } \\
\text { Tamba }\end{array}$ & $\begin{array}{l}\text { Widia } \\
\text { wati }\end{array}$ & $\begin{array}{c}\text { N. } \\
\text { Rambe }\end{array}$ & $\begin{array}{l}\text { Widia } \\
\text { wati }\end{array}$ & $\begin{array}{l}\text { Widia } \\
\text { wati }\end{array}$ & $\begin{array}{c}\text { N. } \\
\text { Rambe }\end{array}$ & $\begin{array}{c}\text { H. } \\
\text { Tamba }\end{array}$ & $\begin{array}{l}\text { Widia } \\
\text { wati }\end{array}$ \\
\hline 5 & $\begin{array}{l}\text { Rata-rata } \\
\text { Siklus }\end{array}$ & \multicolumn{4}{|c|}{$76,38 \%$} & \multicolumn{4}{|c|}{$87,50 \%$} \\
\hline 6 & $\begin{array}{l}\text { \% Kenaikan } \\
\text { Siklus } 1 \text { ke } \\
\text { Siklus } 2\end{array}$ & \multicolumn{8}{|c|}{$18,06 \%$} \\
\hline
\end{tabular}

Tabel 10. Rangkuman Hasil Observasi Aktivitas Siswa Siklus 1 - Siklus 2

\begin{tabular}{|c|c|c|c|c|c|c|c|c|c|c|c|}
\hline \multirow{4}{*}{$\begin{array}{l}\text { Nilai dan } \\
\text { Kategori }\end{array}$} & \multirow{2}{*}{\multicolumn{4}{|c|}{$\begin{array}{c}\text { SIKLUS } 1 \\
\text { Pertemuan }\end{array}$}} & \multirow{4}{*}{$\begin{array}{c}\text { Rata } \\
\text {-rata } \\
\%\end{array}$} & \multirow{2}{*}{\multicolumn{4}{|c|}{$\begin{array}{c}\text { SIKLUS } 2 \\
\text { Pertemuan }\end{array}$}} & \multirow{4}{*}{$\begin{array}{l}\text { Rata- } \\
\text { rata } \%\end{array}$} & \multirow{4}{*}{$\begin{array}{c}\% \\
\text { Kenaikan } \\
\text { Siklus } 1 \\
\text { ke Siklus } \\
2\end{array}$} \\
\hline & & & & & & & & & & & \\
\hline & 1 & 2 & 3 & 4 & & 5 & 6 & 7 & 8 & & \\
\hline & Skor & Skor & Skor & Skor & & Skor & Skor & Skor & Skor & & \\
\hline Skor & 62 & 67 & 70 & 73 & 68 & 74 & 77 & 80 & 82 & 78.25 & \multirow[b]{2}{*}{$12,05 \%$} \\
\hline $\begin{array}{c}\text { Persentas } \\
\mathrm{e}\end{array}$ & $\begin{array}{c}72,9 \\
9 \\
\end{array}$ & $\begin{array}{c}78,8 \\
8 \\
\end{array}$ & $\begin{array}{c}82,3 \\
5\end{array}$ & $\begin{array}{c}85,8 \\
3\end{array}$ & $\begin{array}{c}79,9 \\
5 \\
\end{array}$ & 87,03 & 90,51 & 94,12 & 96,39 & 92,00 & \\
\hline Kategori & Baik & Baik & Baik & Baik & Baik & $\begin{array}{c}\text { Baik } \\
\text { sekali }\end{array}$ & $\begin{array}{c}\text { Baik } \\
\text { sekali }\end{array}$ & $\begin{array}{c}\text { Baik } \\
\text { sekali }\end{array}$ & $\begin{array}{c}\text { Baik } \\
\text { sekali }\end{array}$ & $\begin{array}{c}\text { Baik } \\
\text { Sekali }\end{array}$ & \\
\hline Observer & HT & WD & NR & WD & & WD & NR & HT & WD & & \\
\hline
\end{tabular}

\section{Refleksi terhadap Hasil Pembelajaran Biologi Siswa pada Siklus 2}

Tabel 11. Nilai rata-rata Ketuntasan Belajar Siswa Pra Siklus, Siklus 1 dan 2

\begin{tabular}{|c|c|c|c|}
\hline Nilai & Pra Siklus & Siklus 1 & Siklus 2 \\
\hline Nilai terendah & 10 & 20 & 40 \\
\hline Nilai tertinggi & 70 & 75 & 95 \\
\hline Nilai rata-rata & 38.63 & 63.52 & 76.7 \\
\hline
\end{tabular}

Tabel 12. Persentase Ketuntasan Belajar Siswa Pra Siklus, Siklus 1 dan Siklus 2 


\begin{tabular}{|c|c|c|c|c|c|c|c|c|c|}
\hline \multirow{3}{*}{ No } & \multirow{3}{*}{ Nilai } & \multirow{3}{*}{ KKM } & \multicolumn{6}{|c|}{ Ketuntasan Belajar Siswa } & \multirow{3}{*}{$\begin{array}{c}\text { Peningkatan } \\
\text { Pra Siklus- } \\
\text { Siklus } 2\end{array}$} \\
\hline & & & \multicolumn{2}{|c|}{ Pra Siklus } & \multicolumn{2}{|c|}{ Siklus 1} & \multicolumn{2}{|c|}{ Siklus 2} & \\
\hline & & & Jumlah & $\%$ & Jumlah & $\%$ & Jumlah & $\%$ & \\
\hline 1 & $\geq 70$ & Tuntas & 4 & 9 & 27 & 61,36 & 38 & 86,36 & \\
\hline 2 & $<70$ & Tidak tuntas & 40 & 91 & 17 & 38,64 & 6 & 13,64 & \\
\hline 3 & Max & & & & 70 & 75 & & 95 & $77.36 \%$ \\
\hline 4 & Min & & & & 10 & 20 & & 40 & \\
\hline 5 & Mean & & & & 38,36 & 63,52 & & 76,70 & \\
\hline
\end{tabular}

\section{Refleksi terhadap Minat Belajar Siswa pada Siklus 2}

Tabel 13. Rekapitulasi Hasil Angket Minat Belajar Siswa Siklus 1-Siklus 2

\begin{tabular}{|c|c|c|c|c|c|c|}
\hline \multirow{2}{*}{$\begin{array}{l}\mathrm{N} \\
\mathrm{o}\end{array}$} & \multirow[b]{2}{*}{ Indikator } & \multicolumn{2}{|c|}{ Siklus 1} & \multicolumn{2}{|c|}{ Siklus 2} & \multirow{2}{*}{$\begin{array}{c}\% \\
\text { Peningkatan }\end{array}$} \\
\hline & & $\begin{array}{l}\text { Rata-rata } \\
\text { Indikator }\end{array}$ & $\begin{array}{c}\text { Kriteri } \\
\text { a }\end{array}$ & $\begin{array}{l}\text { Rata-rata } \\
\text { Indikator }\end{array}$ & Kriteria & \\
\hline 1 & Sikap dalam belajar & 3,00 & Baik & 3,26 & $\begin{array}{c}\text { Baik } \\
\text { Sekali }\end{array}$ & 8,71 \\
\hline 2 & Kemauan belajar & 3,04 & Baik & 3,18 & Baik & 4,54 \\
\hline 3 & Ketertarikan dalam belajar & 2,50 & Cukup & 3,04 & Baik & 21,64 \\
\hline 4 & Dorongan belajar & 2,65 & Baik & 3,02 & Baik & 14,07 \\
\hline 5 & Ketekunan dalam belajar & 2,92 & Baik & 3,22 & Baik & 10,26 \\
\hline 6 & $\begin{array}{l}\text { Perhatian dalam aktivitas } \\
\text { belajar }\end{array}$ & 3,08 & Baik & 3,25 & Baik & 5,37 \\
\hline & Jumlah & 17,19 & & 18,97 & & 64,59 \\
\hline & Rata-rata & 2,87 & & 3,16 & & 10,76 \\
\hline
\end{tabular}

\section{Pembahasan}

Guru memiliki peran yang sangat penting dalam proses pembelajaran. Kunci kesuksesan pembelajaran di sekolah yang pertama dan utama adalah terletak pada kemampuan profesional guru dalam mengelola pembelajaran. Tujuan pembelajaran dapat direncanakan bersama oleh guru dan siswa, namun penentuan media dan model strategi belajar lebih berpusat pada guru. Sistem perencanaan dan pengelolaan pembelajaran yang baik akan menjamin terjadinya proses belajar yang efektif pada siswa, terutama melalui pengamatan, mendengarkan, dan resitasi yang terencana.

Sukmadinata (2008:55) mengemukakan bahwa belajar merupakan usaha untuk mengembangkan pemahaman tingkat tinggi pada siswa. Pemahaman yang bermutu tinggi adalah pemahaman yang teruji, yang berisi kecakapan menggunakan suatu objek, fakta atau proses ataupun ide dalam berbagai situasi. Untuk menciptakan tumbuhnya kondisi pembelajaran tersebut, seorang guru dituntut untuk mendesain pembelajaran efektif. Proses pembelajaran yang efektif tentunya amat tergantung pada berbagai komponen pembelajaran, salah satu komponen tersebut adalah multimedia pembelajaran interaktif. Impelementasi multimedia pembelajaran pada prinsipnya ditujukan untuk mencapai berbagai target, misalnya pencapaian hasil belajar, peningkatan atensi belajar dan minat belajar siswa atau juga membantu memperluas dan memperdalam wawasan siswa. Oleh sebab itu, seorang guru perlu mendesain terlebih dahulu media pembelajaran yang mampu menyajikan informasi pembelajaran yang menarik kepada siswa sehingga tujuan pembelajaran dapat dicapai.

Sesuai dengan pendapat Robert $L$. Solso (2008: 194) yang menyatakan bahwa informasi yang tidak mendapatkan atensi penuh dan dianalisis hanya secara dangkal oleh siswa akan segera dilupakan, sedangkan informasi yang atensi penuh dari siswa dan diproses secara mendalam akan diperkaya dengan asosiasi citra tentu akan bertahan lebih lamadalam ingatan. Di sinilah salah satu peran 
utama dari implemetasi media dalam pembelajaran.

Hasil pengamatan pengelolaan pembelajaran yang dilakukan guru berupa tindakan pembelajaran memanfaatkan MPI secara deskriptif telah menunjukkan peningkatan ketuntasan belajar pada tindakan siklus I menjadi mencapai ketuntasan belajar secara klasikal, yakni $86,36 \%$ dengan pada tindakan siklus II. Keberhasilan siswa dalam mencapai ketuntasan belajar ini diakui sebagai dampak dari penerapan media MPI yang mampu membantu siswa memahami materi ajar dengan pendekatan eksperimentasi dan teoretis dalam kegiatan belajar.

Fakta yang diuraikan di atas sejalan dengan Teori Kognitif Multimedia Learning Mayer (2009: 108) yang menyatakan bahwa salah satu pengaruh multimedia dalam pembelajaran adalah dapat meningkatkan hasil tes retensi siswa. Para siswa akan berkinerja lebih baik untuk retensi verbal saat mereka belajar dengan teks dan ilustrasi atau narasi dan animasi dari pada siswa yang belajar hanya menggunakan teks saja.

Lebih lanjut Mayer (2009: 276) juga mengemukakan salah satu interpretasi konsisten dengan impelementasi multimedia pembelajaran adalah bahwa siswa akan bekerja lebih keras untuk menalar materi ajar saat mereka terlibat langsung dalam interaksi sosial. Dalam penelitian ini bentuk interaksi sosial ini adalah hubungan media pembelajaran dengan guru-siswa, siswa-siswa dengan memberi peluang dalam bentuk diskusi. Pendapat ini juga didukung oleh UNESCO (2009: 108) yang menyatakan bahwa pemeragaan situasi yang sederhana bisa memberikan kesempatan untuk memecahkan masalah sama yang sebenarnya sebagai pengganti dari masalah artifisial.

Perencanaan dan pengelolaan pembelajaran yang baik oleh guru tentunya akan membantu guru untuk lebih mengarahkan aktivitasnya di kelas kepada upaya-upaya membelajarkan siswa. Dari hasil penelitian ini ditunjukkan bahwa aktivitas yang tinggi yang dilakukan guru di siklus 1 pada kategori: (2) memotivasi siswa; (3) menjelaskan strategi belajar khusus yang akan digunakan; (4) memodelkan dan melatihkan strategi belajar yang digunakan; dan (5) membimbing siswa mempraktekkan strategi belajar yang dilatihkan; (1) mendengarkan/memperhatikan penjelasan guru; dan (2) diskusi antara siswa dan guru; serta meningkatkan aktivitas: (3) diskusi antar siswa; dan (4) mempraktekkan strategi belajar yang dilatihkan pada siklus 2 .

Konstruktivisme

memandang perkembangan kognitif sebagai suatu hasil pertumbuhan dari perkembangan sosial melalui interaksi dengan orang lain yang terjadi dalam zona perkembangan terdekat anak-anak, dimana anak-anak dapat melakukan tugas-tugas baru yang berada dalam kemampuan meraka dengan bantuan guru atau teman sebaya. Diskusi merupakan komunikasi, dimana siswa berbicara dengan siswa yang lain, saling membagi gagasan dan pendapat. Di titik inilah salah satu peran penggunaan MPI yang memungkinkan siswa agar lebih berinteraksi efektif dalam belajar.

Sesuai pendapat Rusman (2011: 177) yang menyatakan bahwa penerapan media pembelajaran dapat mengembangkan kemampuan softskill dan hardskill siswa. Paling kurang penerapan multimedia pembelajaran memberikan beberapa nilai-nilai positif, seperti: (a) membantu siswa memahami konsep abstrak menjadi lebih konkrit, (b) memperkelas pesan, (c) kontekstual, (d) menimbulkan motivasi, kreativitas dan inovasi siswa dan (e) mengontrol kecepatan belajar siswa.

Atas dasar pada pemikiran tersebut, tindakan pembelajaran yang dilakukan berikutnya adalah menerapkan model pembelajaran diskusi dengan menggunakan media MPI. Kualitas pembelajaran diindikasikan dari: (a) kemampuan guru mata pelajaran mengelola pembelajaran; (b) kecenderungan aktivitas guru selama proses pembelajaran; (c) kecenderungan aktivitas siswa selama proses pembelajaran; (d) keterampilan siswa dalam berdiskusi; dan (e) respon siswa terhadap media pembelajaran yang digunakan. Selanjutnya kualitas hasil belajar akan tergambar dari ketuntasan belajar individual dan klasikal siswa.

Hasil pengamatan aktivitas guru dan siswa juga menunjukkan kecenderungan peningkatan aktivitas mengamati kegiatan siswa dan mengajukan pertanyaan. Penyampaian materi dalam bentuk ceramah sudah sedikit sekali dilakukan guru, lebih dominan siswa mempelajari materi menggunakan MPI, sedangkan penjelasan guru dengan ceramah sifatnya hanya menambahkan atau mengklarifikasi saja agar siswa tidak keliru memahami materi. Selama proses pembelajaran guru hanya menyajikan cuplikan materi dengan 
MPI sebagai kerangka awal bagi siswa berpikir atau belajar lanjut secara pasangan kelompok.

Seperti yang dikemukakan oleh Munir (2008: 88), bahwa salah satu ciri pembelajaran aktif adalah, selama proses belajar mengajar berlangsung, guru bukan hanya menyampaikan materi ajar, tetapi juga menciptakan kondisi agar terjadi proses belajar siswa sehingga dapat mempelajari materi ajar sesuai dengan tujuan yang diharapkan, juga membantu melatihkan dan mengembangkan keterampilanketerampilan interpersonal siswa dalam kelompok.

Hal ini sejalan dengan pendapat Munir (2008: 92) tentang teori konstruktivisme dalam pembelajaran IPA yang menyatakan bahwa pembelajaran konstruktivisme menekankan pembelajaran dengan melalui pengalaman langsung oleh siswa. Pembelajaran merupakan kerja mental aktif, bukan menerima pengajaran secara pasif. Dalam kerja mental siswa, guru memegang peranan penting dengan cara memberikan dukungan, tantangan berpikir, melayani sebagai pelatih atau model, siswa tetap merupakan kunci pembelajaran. Mulyasa (2007: 4) menyatakan bahwa bahwa pembelajaran perlu lebih menekankan pada kegiatan individual siswa dan memperhatikan kondisi belajar yang kondusif dengan metode dan media pembelajaran yang sesuai.

\section{PENUTUP}

\section{Simpulan}

Mengacu pada uraian data hasil penelitian tindakan dan pembahasan yang telah dipaparkan pada bab sebelumnya, maka dapat disimpulkan bahwa:

1. Penerapan media MPI dalam pembelajaran dapat memperbaiki kondisi pembelajaran dalam upaya meningkatkan hasil belajar biologi siswa. Siswa yang berhasil mencapai ketuntasan belajar pada pra siklus sebanyak 4 orang, pada siklus 1 sebanyak 27 orang dan pada siklus 2 sebanyak 38 orang.

2. Besarnya peningkatan ketuntasan belajar siswa dari pra siklus ke siklus 1 , dari siklus 1 ke siklus 2 dan di akhir siklus 2. Secara keseluruhan besarnya persentase ketuntasan belajar siswa sebelum dan setelah penerapan MPI mencapai nilai 77,36\%.

3. Penerapan MPI dalam pembelajaran dapat memperbaiki kondisi pembelajaran dalam upaya meningkatkan minat belajar biologi siswa. Minat belajar biologi siswa pra siklus mencapai nilai rata-rata 2,50 (kategori cukup), pada siklus 1 mencapai nilai ratarata 2,87 (kategori baik) dan pada akhir siklus 2 diperoleh nilai rata-rata 3,16 (kategori baik).

4. Besarnya peningkatan minat belajar biologi siswa dari pra siklus ke siklus 1 dari siklus 1 ke siklus 2 meningkat dan secara keseluruhan besarnya peningkatan persentase minat belajar biologi siswa sebelum dan setelah penerapan MPI mencapai nilai $64,59 \%$.

\section{Saran}

1. Mencermati perkembangan era informasi digital yang juga merambah dunia pendidikan, siswa telah mampu menggunakan sumber belajar yang beragam, namun sebatas buku-buku pelajaran yang mereka miliki dan tersedia di perpustakaan sekolah. Karena itu ke depan, perpustakaan sekolah perlu disiapkan dengan berbagai sumber belajar terutama multimedia pembelajaran interaktif, juga sumber belajar buku-buku teks dalam format digital dan CD/DVD pembelajaran. Karena pada kenyataannya, keberadaan berbagai media belajar tersebut dapat digunakan untuk memperbaiki kondisi pembelajaran siswa.

2. Agar penggunaan media MPI sebagai media belajar efektif dalam penggunaannya, maka guru disarankan untuk melatih siswa terlebih dahulu dengan keterampilan strategi belajar seperti keterampilan membaca, memberi tanda, pemetaan konsep, dan sebagainya agar dapat memanfaatkan sumber media belajar interaktif yang tersedia untuk menggali informasi terkait dengan materi kajian pembelajaran secara efektif.

3. Dengan desain model yang telah disusun ini, diharapkan guru mata pelajaran biologi dapat mengembangkan dan mendesain penerapan MPI sesuai dengan kebutuhan/kondisi siswa dan sekolah. Sebab, pembelajaran dengan hanya menggunakan satu model saja tidak selamanya baik untuk semua topik kajian mata pelajaran, karena itu kreativitas guru dalam melakukan tindakan yang berulangulang akan memberikan hasil berupa modelmodel pembelajaran berbasis multimedia pembelajaran interaktif yang sesuai dengan kekhasan materi ajar.

\section{DAFTAR PUSTAKA}


Arsyad, A. 2002. Media Pembelajaran. Jakarta: PT. Raja Grafindo Persada.

Briggs, Leslie J. 1979. Instructional Design: Principles and Aplication. Engelwood Cliffs, New Jersey: Prentice-Hall,Inc.

Connel, H. 2003. Reformasi Pendidikan. Jakarta: PT. Logos Wacana Ilmu

Djamarah, Syaiful Bahri dan Zain Azwan. 2002. Strategi Belajar Mengajar. Jakarta: Rineka Cipta.

Fraenkel, J. R. dan Wallen, N. E. 1993. How to Design and Evaluate Research in Education (Second ed.). New York: McGraw-Hill Book Co.

Gagne, 1977. The Conditions of Learning and Theory of Instructions. $4^{\text {th }} \mathrm{ed}$. New York: Holt Rinehart \& Winston.

Gerlach dan Ely. 1971. Learning To Teach. Sixth Edition. New York. McGraw-Hill Co. Inc.

Hamalik, O. 2008. Manajemen Pengembangan Kurikulum. Bandung: PT. Remaja Rosdakarya.

Hergenhahn, B.R. Theories of Learning. Jakarta: Kencana Prenada Media Group

Hurlock, 2009. Perkembangan Anak Jilid 1, Jakarta: Erlangga.

Indrajit, R.E., R. Djokopranoto. 2008. Manajemen Perguruan Tinggi Moderen. Yogyakarta: CV. Andi Offset.

Jalal, F., Dedi Supriyadi. Reformasi Pendidikan dalam Konteks Otonomi Daerah. Jakarta: Depdiknas-Bappenas-Adicita Karya Nusa

Joyce, Bruce dan Marsha Weil. 2009. Models of Teaching. Boston: Pearson Education. Inc

McGinn, N., T. Welsh. 2003. Desentralisasi Pendidikan. Jakarta: Logos Wacana Ilmu

McMahon, Walter W. 2003. Sistem Informasi Manajemen Berbasis Efisiensi. Jakarta: Logos Wacana Ilmu.

Morison, Gary M.,Steven M. Ross dan Jerold E. Kemp. 2001. Designing Effective Instruction. New York: John Wiley \& Sons, Inc.

Muhibbin Syah, 2001. Psikologi Pendidikan dengan pendekatan Baru, Cet. Ke-6. Bandung: PT. Remaja Rosdakarya.

Mulyasa, E. 2007. Menjadi Kepala Sekolah yang Profesional. Bandung: PT. Remaja Rosdakarya.

Munir, 2008. Kurikulum Berbasis TIK. Bandung: CV. Alfabeta
Muslich, M. 2009. Melaksanakan Penelitian Tindakan Kelas Itu Mudah. Jakarta: Bumi Aksara

Nelson, Kristen. 2001. Teaching in the Cyberage: Lingking the Internet and Brain Theory. Arlington Heights, Illionis: SkyLight training and Publishing Inc

Purwanto, 2008. Penerapan Model Pembelajaran Kooperatif Tpe Jigsaw sebagai Upaya Peningkatan Kinerja Dan Prestasi Belajar Fisika di SMK Negeri 3 Yogyakarta. Yogyakarta . Persentasi PTK Tanggal 5 Nopember 2008.

Rose, Colin dan Malcolm J. Nichols. 2002. Accelerated Learning. Bandung: Nuansa

Rusman, 2011. Pembelajaran Berbasis TIK. Jakarta: Raja Grafindo Persada.

Sagala, S. 2010. Manajemen Strategik dalam Peningkatan Mutu Pendidikan. Bandung: Alfabeta

Sanjaya, 2007. Strategi Pembelajaran; Berorientasi Standar Proses Pendidikan. Jakarta : Kencana.

Schunk, Dale H. 2012. Learning Theories: An Educational Perspective. Yogyakarta: Pustaka Pelajar

Silberman, Mel. 2001. Active Learning. Yogyakarta: Yappendis

Slameto, 2003. Belajar Dan Pembelajaran, Surabaya, Rahayu Cipto.

Solso, Robert L. dan Otto H. Maclin, M. Kimberly Maclin. 2008. Psikologi Kognitif. Edisi Kedelapan. Jakarta: Erlanggga

Sukmadinata, Nana Syaodih. 2008. Pengembangan Kurikulum: Teori dan Praktek. Bandung: Remaja Rosdakarya Offset.

Tim Pengembangan Ilmu Pendidikan, FIP-UPI. 2007. Ilmu dan Aplikasi Pendidikan. Bandung: PT. Imperial Bhakti Utama

Trianto, 2012. Mendesain Model Pembelajaran Inovatif-Progresif: Konsep, Landasan, dan Implementasinya pada Kurikulum Tingkat Satuan Pendidikan (KTSP).Jakarta: Kencana

UNESCO, 2009. Teknologi Informasi dan Komunikasi dalam Pendidikan. Jakarta: Gaung Persada Press

W. Gulo, 2005. Strategi Belajar Mengajar, Jakarta:Grasindo. 